\title{
Articles
}

http://dx.doi.org/10.15762/ZH.2018.55

NATALIA BURSIEWICZ

(Pedagogical University of Cracow)

\section{Three-Dimensional Aspect of the Town and Fortress ON THE EXAMPLE OF ZaMośĆ*}

Key words: spatial analysis of Zamość, town planning, fortress town, Zamość Fortress, Zamość (Province of Lublin), spatial planning

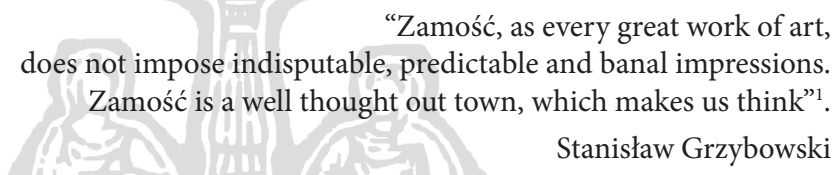

"The construction of the town is not limited to a two-dimensional plan Zamość was also designed in a three-dimensional plan"2. This quotation became the starting point to reflect upon the spatial, multi-dimensional layout of the town, its image and long history. Jerzy Kowalczyk, focusing on the ideological conception of the founder and selected urban aspects: the composition of the plans and names of the streets along with architectural elements, looked closely at the 'inner part' of the town. This article emphasizes the external image of Zamość as an artistic-urban phenomenon including elements of an architectural and sculptural work of art. The article also includes the analysis of the relation of three-dimensional figures to each other and the axis which may be drawn between the crucial points. The town "was not designed as a plan, but as a three-dimensional figure" - as the most acute analyst of Zamość, Stanisław Herbst ${ }^{3}$, points out. For this reason the problem concerning the pres-

* The article was written as a part of the research project "Historical Atlas of Polish Towns", financed by the Ministry for Science and Higher Education, within the programme Narodowy Program Rozwoju Humanistyki ["The National Programme for the Development of Humanities"], no. $11 \mathrm{H} 16020984$.

${ }^{1}$ Stanisław Grzybowski, Trzynaście miast. Czyli antynomie kultury europejskiej, Wrocław 2000, p. 173.

${ }^{2}$ Jerzy Kowalczyк, Ideologiczne aspekty urbanistyki Zamościa, [in:] Zamość i Zamojszczyzna w dziejach i kulturze polskiej, ed. Kazimierz MrśLIŃski, Zamość 1969, p. 140.

${ }^{3}$ Stanisław Herbst, Zamość, Warszawa 1954, p. 16. 
entation of Zamość may be considered multi-dimensionally: from the point of view of the methodology of the history of art (geography of perception), the perception of a work of art, aesthetics, the theory of architecture. Assuming that the town of Zamość is examined as a work of art, it possesses a certain characteristic value; there appears a possibility of it being interpreted in various terms: figurative, emotive, appealing, aesthetic and metaphysical.

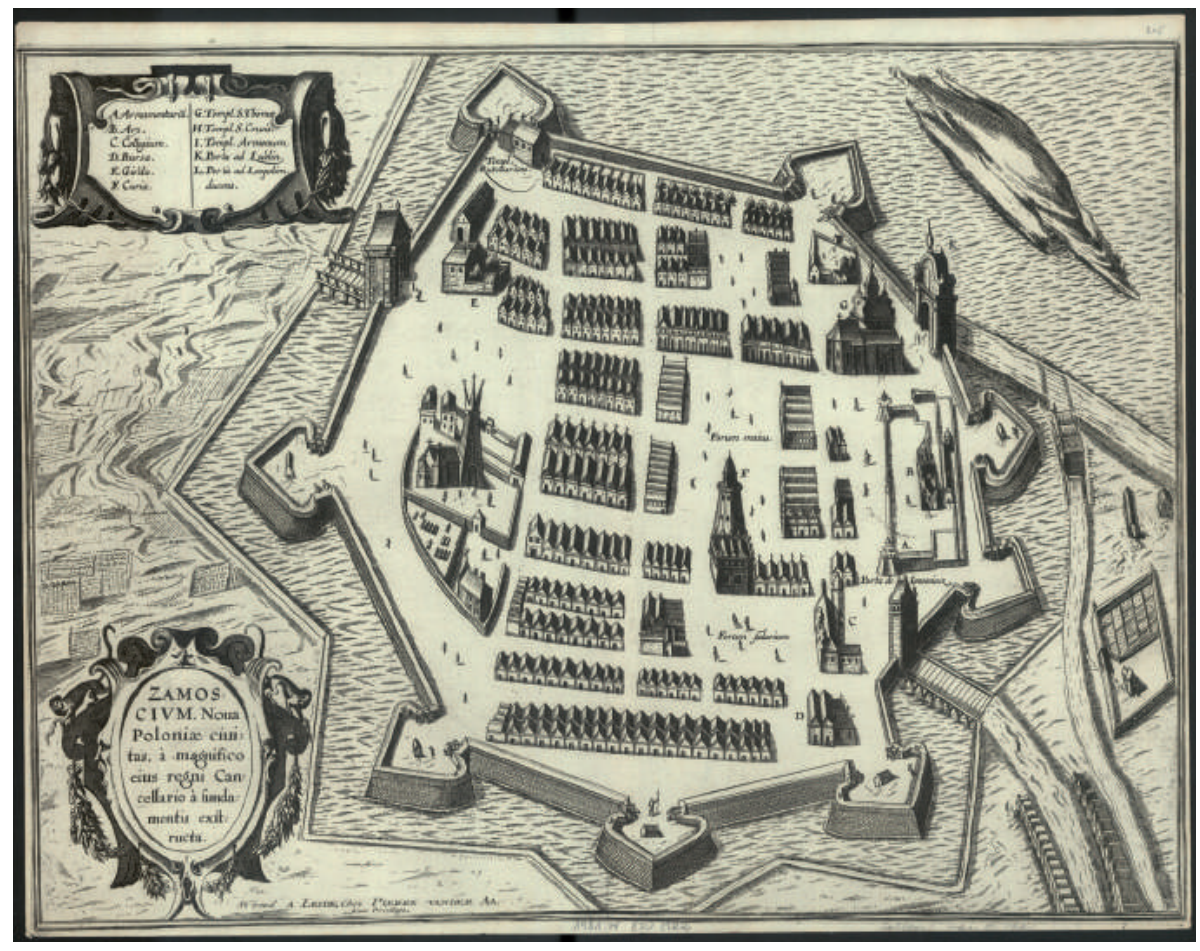

Il. 1. Plan of Zamość based on the plan of Braun \& Hogenberg. Zamoscium. Noua Poloniae ciuitas, a magnifico eius regni cancellario a fundamentis exstructa, published by Pieter van der Aa in Leiden in 1728

Every three-dimensional figure, particularly the one bearing sculptural features is placed on a given surface, which constitutes its foundation. Zamość was situated on a flat elevation, on "somewhat wavy fields" as wrote Maria Dąbrowska, at the confluence of the Łabunka nad Topornica rivers, at the intersection of two important roads from Lublin to Lviv and from Ruthenia to $\mathrm{Cracow}^{4}$.

${ }^{4}$ Maria DąBrowska, Tydzień $w$ Lubelskiem, Bluszcz. Pismo tygodniowe ilustrowane dla kobiet, vol. 31: 1925, no. 28 (July 11, 1925), p. 873. 
The plan of the town in a form of a prolonged pentagon resembling a star was probably based on the Vitruvian scheme of the city ${ }^{5}$. According to Siegfried Giedion, this kind of central layout constituted an excellent logical concept $^{6}$. It was also one of the few citta ideale in Europe. It was associated with the idealistic and symbolical composition based on the circle, which may be associated with the idea of the central authority ${ }^{7}$. Zamość, planned to be the capital of the Ordination within the territory of which the main seat of the administrator was situated, was consistent with the above-mentioned concept. This ideal plan was to consist of the pragmatically laid down building complex. In this way two surfaces - the flat one and the three-dimensional one - were to constitute two components complementing each other. When Jan Zamojski asked Bernard Morando "to paint the layout of the square of the town" - he wanted to acquire the complete concept of the town which included its buildings and fortifications, taking into account its commercial and political functions ${ }^{8}$. The essence of Zamość was the combination of the fortification plan with the plan of the inner part of the town. A good example illustrating the juxtaposition of the silhouette of the town with its plan is the Swedish plan of Zamość of 1704 preserved in the Museum of Zamość ${ }^{9}$. The plan reflects the outline of the fortifications, the moat, the reservoir, quarters of the building complexes along with the key edifices and the panoramic view from the north.

The perceptible stereometric layout of the whole complex, which consists in the closed building composition, defines the figurative value of Zamość. Its boundaries are marked by the fortification ring informing about the defensive aspect of the town's foundation. The aesthetic object, while concentrating on itself, refers to multifaceted aspects, which creates a twofold image: the external one and the internal one. The former is the creation of the perception,

${ }^{5}$ See the plan of Zamość included in the work by Andreas Cellarius, Regni Poloniae Magnique Duccatus Lithuaniae [...] studio, Amsterdam 1659, Muzeum Zamojskie, Archiwum historyczne, available at: http://muzeum-zamojskie.pl/zbiory/katalog/upload/49.jpg [Accessed 10.12.2018].

${ }^{6}$ Siegfried Giedion, Przestrzeń, czas i architektura. Narodziny nowej tradycji, trans. Jerzy OlKiewicz, Warszawa 1968, p. 79.

${ }^{7}$ Rafał Eysymontт, Kod genetyczny miasta. Średniowieczne miasta lokacyjne Dolnego Ślaska na tle urbanistyki europejskiej, Wrocław 2009, pp. 72-73.

${ }^{8}$ Wojciech Kalinowski, Zamość idealne miasto renesansu, [in:] Czterysta lat Zamościa. Materiały sesji naukowej zorganizowanej przez Wydział I Nauk Społecznych Polskiej Akademii Nauk, Uniwersytet im. Marii Curie Skłodowskiej w Lublinie, Zamojskie Towarzystwo Przyjaciót Nauk, 12-13 czerwca 1980 r. w Zamościu, ed. Jerzy Kowalczyк, Wrocław 1983, p. 90.

${ }^{9}$ The description of the plan is available in Polska Biblioteka Cyfrowa: Aleksander CzoŁowski, Plan i widok Zamościa z roku 1704, Zamość 1929, https://polona.pl/item/plan-i-widok -zamoscia-z-roku-1704,MjUyNTUxMTc/17/\#info:metadata [Accessed 10.12.2018]. 
whilst the other is the fruit of individual allegorization ${ }^{10}$. Fortifications created a visibly outlined division line, which was the symbolic message: it is a townfortification. Fortifications, defensive ramparts, the moat, the reservoir from the south-west constituted a well thought-out concept in accordance with the premises of the military treatises of the time, the character of military actions and the political situation. The evidence for this are the words of Jan Zamojski: "Taking into account the security of myself, my friends, all the neighbours and subordinates from the adjacent villages, I decided to build a town [...] fortified with ramparts and a moat, for which I shall pay"11. In this way, Zamojski identified himself with the historical role of the ruler, who is responsible for the safety of his people and builds e.g. defensive walls. Apart from the function of the asylum, the defensive walls were the evidence of the power of the town's founder, the characteristic landmark allowing to identify the town. They formed the silhouette of the town, which served to promote Zamość as an imposing, monumental and unconquerable town. It was reflected in numerous descriptions filled with emotionally loaded adjectives. Bonifacius Vanozzi in 1596 wrote about the heavily fortified fortress, while Georg Dous in 1598 mentioned huge defensive walls strengthened by fortified towers ${ }^{12}$. At the end of the $16^{\text {th }}$ century Hugo Grocjusz compared Zamośc with Rome ${ }^{13}$. The above mentioned descriptions are consistent with the frequently appearing image of the town as laudation urbis. The fortifications were to generate fear, which may be compared to the effect of the Gorgon's head. Like Athena, who placed Medusa's head on her shield to intimidate her enemies and force them to run away, Zamojski erected fortifications strengthened with the ramparts and the moat. The solution was effective for a long time. Neither Chmielnicki in 1648 nor the Swedes in 1656 managed to conquer Zamość, which was vividly depicted by Henryk Sienkiewicz in his novel Potop. It was in Zamość that Zagłoba, one of heroes of the novel, advised Jan Zamojski "to donate the Netherlands to the Swedish king instead"14 when Carl Gustav wanted to give the Province of Lublin to Zamojski in return for opening the gates of Zamość.

${ }^{10}$ Hans Belting, Antropologia obrazu. Szkice do nauki o obrazie, trans. Mariusz BrYL, Kraków 2007, p. 12.

${ }^{11}$ Przywilej lokacyjny Zamościa z 1580 roku, ed. Ryszard Szczygie£, Lublin 1980.

${ }^{12}$ The description by Bonifacius Vanozzi see: Julian Ursyn Niemcewicz, Zbiór pamiętników historycznych o dawnéy Polszcze z rękopismów, tudzież dzieł w różnych językach o Polszcze wydanych oraz z listami oryginalnemi królów i znakomitych ludzi w kraju naszym, vol. 2, Warszawa 1822, p. 187; the description by Georg Douse see: Julian KrZYŻanowski, Uczony holenderski na hetmańskim dworze, Teka Zamojska, vol. 1: 1938, no. 1, p. 28, http://dlibra.kul.pl/ Content/38138/42097_V-2122_Teka-Zamojska--R--2--01.pdf [Accessed 10.12.2018].

${ }^{13}$ For: Andrzej KęDZiona, Encyklopedia miasta Zamościa, Chełm 2000, p. 265.

${ }^{14}$ Henryk Sienkiewicz, Potop, vol. 3, Warszawa 1957, pp. 26-39. 
The paintings presenting Zamość also played a major role in shaping the image of the town. The first image of Zamość of 1617 contributed to the creation and popularization of the image of the town and fortress of Zamość enriched with a variety of symbolical spatial elements ${ }^{15}$. On the basis of this plan, subsequent plans were generated, which is the evidence of the significance of Zamość. This image came back through centuries in numerous versions - always with the fortifications playing the key role. They were normally placed at the eye level of the observer. A case in point may be the Panorama of Zamość from the south-western part on the lithography by August Bovet, and others ${ }^{16}$ (il. 1). Thanks to such a composition, the message was clear - Zamość was a fortress.

The form of the town influences directly the experience of its form. It stimulates a certain kind of reception. In the image by Bruder (1820) and Lelewel (1825) the recipient is placed in the position of the assaulter ${ }^{17}$. The first element that the observer notices is the fortification ring. Then, they notice individual objects, which affect the specific reception of the whole image. Such an image of the town was one of the main aims of the municipal policy in the territory of whole Europe. It was a deliberate action based on the manipulation of the perspective, which was to suggest the appropriate reception of the image and its message. The line of the horizon which marked the level of the observation implies the emphasis on its defensive role. The location of the town served the same purpose. Maria Dąbrowska wrote that "Zamość is visible from the

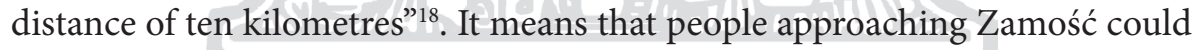
observe its silhouette for a long time, which was becoming more and more discernible and mighty. The impression was equally strong in the vicinity of the defensive walls, the evidence of which are the words of Julian Ursyn Niemcewicz of 1815: "having entered it [Zamość - N.B.] I was struck with the magnificence of the walls"19. Such an image of the town survived for centuries owing

${ }^{15}$ The plan and panorama of Zamość at the beginning of the $17^{\text {th }}$ century included in $\mathrm{Ci}$ vitates Orbis Terrarum, vol. 6, the copperplate by Franc Hogenberg issued by Georg Braun in Cologne in 1617.

${ }^{16}$ August Andre Bovet, Zamoski, ville de Pologne au palatinate de Belz, Généve 1815-1853, https://polona.pl/item/zamoski-ville-de-pologne-au-palatinat-de-belz,Nzg5NDYwMw/0/\# info:metadata [Accessed 10.12.2018].

${ }^{17}$ The general view of Zamość of 1820 in the picture of J. F. Bruder. F. Bruder ad Vivam, Vue de Zamoski peint par Bruner 1818, [in:] Stanisław Herbst, Jan Zachwatowicz, Twierdza Zamość, Warszawa 1936, p. 119. Panorama of the Zamość Fortress, watercolour by J. P. Lelewel from 1820, see: Wojciech PrZegon, Krajobrazy XIX-wiecznego Zamościa w akwarelach i rysunkach Jana Pawła Lelewela, Kraków 1997.

${ }^{18}$ M. DĄBRowsKa, op.cit., p. 873.

${ }^{19}$ Julian Ursyn Niemcewicz, Juljana Ursyna Niemcewicza, podróże historyczne po ziemiach polskich od 1811 do 1828 roku, Petersburg 1859, p. 144. 
to subsequent extensions of fortifications. Referring to Roman Ingarden, one may suggest that the work of art (Zamość) became concrete in the moment when the recipient looked at it and went towards it. In this perspective the recipient turns out to be indispensable to define the image and its message. Looking at the work of art from many different angles, as Ingarden points out, the recipient may be moved, enchanted or their thoughts may be directed towards a certain idea ${ }^{20}$. In this case, the location, fortifications and gates may affect the way Zamość is perceived owing to the emotions they inspire such as delight, fear, respect, humility. According to Kotler et al., it is the collection of emotions, beliefs, impressions that constitute the image which people have in reference to a given town ${ }^{21}$. The idea is nothing new as it dates back to the Hellenistic period and the term of kosmos eistheros - the world perceived with the senses. However, kosmos noetos - the world perceived by the reason - is also necessary to accomplish the complete understanding. The fragment of Historia Naturalis by Pliny the Elder seems to present it well: "the real apparatus of our sight and observation is our mind; the eyes play the mere role of a vessel, which captures ad transmits part of what is embraced by the consciousness"22.

The inherent part of the city walls were gates. As I have noticed above, both gates and city walls affected the emotive and appealing value generating certain reactions in the recipients, e.g. fear ${ }^{23}$. The city gates, particularly porta triumphalis - expresses worship and the superiority of the authority, just like the triumphal arch.

The Gate of Lublin (1588) from the north, the Gate of Lviv (1597/1599) from the east and the Gate of Szczebrzeszyn (B. Gocman, 1603) from the south constituted explicit composition elements. They also played the symbolic role marking the boundaries of the town. Moreover, on the axis from the Gate of Lublin - porta triumhalis, to the Gate of Lviv there was the most important urban part of the town - the market square and one of the most significant and highest buildings - the Town Hall. When the Gate of Lublin was bricked up (in 1588 to commemorate the ride of captured Archduke Maximillian), the

${ }^{20}$ Roman Ingarden, Studia $z$ estetyki, vol. 2, Warszawa 1958, p. 22.

${ }^{21}$ Patrycja Grzyś, Wizerunek miasta a jego tożsamość - wspótczesne zależności, Architectus, vol. 2 (50): 2017, p. 6. From: Philip Kotler, Christer Asplund, Irving Rein, Donald Haider, Marketing places Europe. How to attract investments, industries, residents and visitors to cities, communities, regions and nations in Europe, London 1999, p. 141.

${ }^{22}$ Pliny the Elder, Historia Naturalis, cit. according to: Ernst Hans Gombrich, Sztuka i złudzenie. O psychologii przedstawienia obrazowego, trans. Jan ZARAŃsKI, Warszawa 1981, p. 24.

${ }^{23}$ A similar situation occurred with Wrocław, which is well visible in the historical images of the city. See the article included in this volume of "Zapiski Historyczne" ["Historical Records"] written by Rafał Eysymontt. 
axis was moved on the line: the Gate of Lviv - the Gate of Szczebrzeszyn, in the vicinity of which there was a collegiate church and the water market. The gates played the propaganda role thanks to inscriptions placed on them. On the Old Tower of Lviv - bearing the image of St. Thomas the Apostle - the patron of the town - kneeling down in front of Christ and decorated with cartouches with three crossed spears (the Jelita coats of arms of the Zamojski family), there were Latin inscriptions: commending the fortress into God's protection and confirming the foundation of Zamojski: "Zwycięzco grzechu, piekła i śmierci odeprzyj wściekłe ataki wszystkich nieprzyjaciół / Roku Pańskiego 1580 Kanclerz Wielki Królestwa Polskiego własnym sumptem począł obwarowywać i zgromadzać osadników oraz nadał imię Nowy Zamość" (the inscriptions are decipherable).

On the Gate of Lublin bearing the bas relief presenting the personification of Polonia sitting on the throne (In Braun there is her description: "There is in this town a magnificent defensive gate, on which there is an image of a queen on the side which faces the suburbs"), there was the Latin inscription written by Jan Zamojski: "Witaj Życiodajna Matko Polsko! Ty nie tylko murami, lecz także życiem i krwią masz być przez nas broniona. O Gwiazdo Wolności i Szlachetności, Polsko, witaj”. In this inscription there appears an image of Zamość which is the reflection of Poland. The next inscription is situated on the moulding divided with the cartouche of the coat of arms of the Zamojski family: "Jan z Zamościa Kanclerz Wielki Królestwa Polskiego i Hetman, generalny wódz wojska $\mathrm{z}$ własnych funduszów wystawił", which again underlines the initiative and creativity of the administrator of the territory.

The Gate of Szczebrzeszyn, modified in the $18^{\text {th }}$ century (Baroque attic with stone vases and sculptures of St. Florian and St. Michale the Archangel the patrons of the senior and junior part of the Zamojski family) and in the $19^{\text {th }}$ century, after bricking up the Old Gate of Lublin, played the role of the major entrance into the town. This gate was more representative than defensive.

The significance of gates - as the representative entrance into the city was underlined not only by means of their height, but also by the effect of them being reflected in the water, which reinforced the message making the gates look much bigger. The inscriptions transmitted a coherent and transparent message in which on one line there appeared the mother - the clan - the town.

Within the fortifications line there appear distinctive elements which reflect the ideological concept of the founder and underline the significance of the mature and well thought out civitas. They are easy to read in the threedimensional composition of Zamość, in the gradation of the height and size of the three-dimension figures. The tower of the town of 1581, despite being the highest (playing the role of the decisive, three-dimensional constitutive element of the town) is much slender than the lower, if monumental, palace 
tower, which also constitutes the significant dominant ${ }^{24}$. The next distinctive towers are the one belonging to the Franciscans and the tower of the Collegiate (the Church of the Resurrection of the Lord and St. Thomas the Apostle) (1587-1598) erected as the votive offering for Zamojski's achievements and mausoleum of his clan. The gradation is very well visible in Widok Zamościa ['The view of Zamość'] by J. F. Bruder of 1821.

The towers visible in the distanc informed about the character and function of the town. They stood out in the silhouette of the town, which emphasized the town's significance. However, it should be stressed that their distribution was not accidental. It was the deliberate decision of the founder/architect, as were most of the elements of the urban composition ${ }^{25}$. The Town Hall and Collegiate were not situated in the town centre, nor in the middle of the square. They were located on both sides of the palace. The Collegiate Church was erected between the market square and the palace, while the Town Hall was built in the northern quarter, on one line with burgher houses. In this way, the palace with the quadrangular tower - belvedere was situated among them, which underlined the position of Zamojski. Moreover, every object was found in the vicinity of a different gate - the Collegiate Church in front of the Gate of Szczebrzeszyn while the Town Hall near the Gate of Lublin. If we were to draw the base of the triangle on the backside of the palace, the triangle's sides would coincide in the angle of the pentagon situated directly on the axis with the palace. Such a symbolic triangle would include the most important buildings of the town. The edifice of the palace stands out in the urban structure, and its qualities are additionally underlined and exposed owing to its location. It should be emphasized that the monumental buildings were laid out in such a way as to make them visible not only in the distance, but also from the perspective of streets. The Collegiate Church is visible from Żeromskiego Street and Stanisława Staszica Street. The Town Hall may be seen from the small streets which lead up to the market square. The palace is visible from the main axis - Grodzka Street.

The layout described above may also be interpreted in reference to the Vitruvian concept of the ideal town-man (the anthropomorphic shape of Zamość). In such a configuration the Zamojski Palace would be the head, the Town Hall would be the heart of the town, the Collegiate Church along with the academy - its lungs, Grodzka Street its spine, and the bastions - its hands and legs ${ }^{26}$.

\footnotetext{
${ }^{24}$ S. Herbst, op.cit., p. 16.

${ }^{25}$ R. EYsymonTt, op.cit., pp. 76-77.

${ }^{26}$ Anna JAwor, Kultura w mieście idealnym. Kultura - Zamość - uczestnictwo w kulturze, Warszawa 2009, p. 85.
} 
The variety of the three-dimensional figures reflects the denominational and social variety in the town. In Zamość there were many temples belonging to various denominations: the Roman Catholic Church, the Armenian Uniate Church, the Greek Catholic Church, the Jewish community.

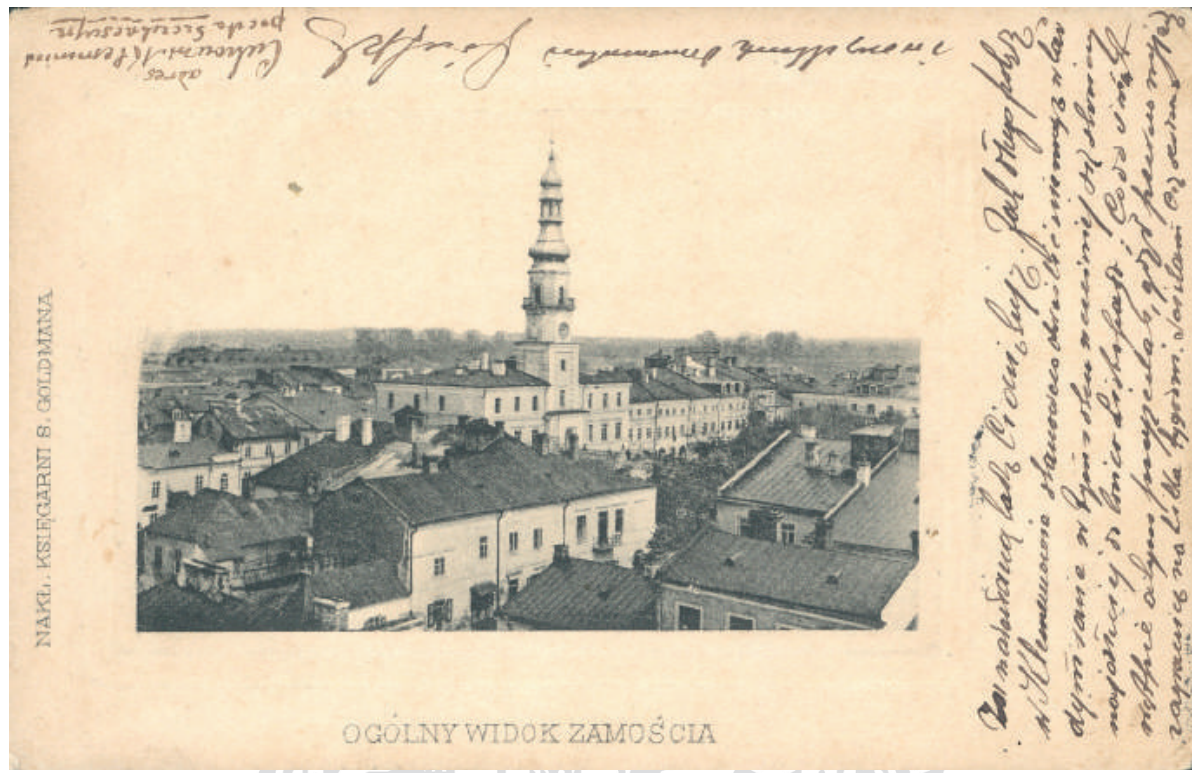

Il. 2. General View of Zamość, published by S. Goldman, Warsaw 1903, Lightpress B. Wierzbicki i Ska

Among the three-dimensional figures of Zamość the most significant were the Arsenal (1582-1583) and the Academic (opening: 1595, the quadrangular edifice: 1639-1648). They were situated on both sides of the palace: the Arsenal in the south, while the Academy in the north. The buildings proudly fulfilled their practical and ideological roles.

Individual buildings, related to each other according to Zamojski's concept, created a marvellous town, for its own honour and for future generations ${ }^{27}$. This magnificence should be also combined with beauty. The idea voluptas put forward by Alberti and followed by the constructors of cities was very popular among the elites and artists of the Renaissance ${ }^{28}$. At that time Vasari's treatise was commonly known; it read that the builders of cities should pay special attention to the 'eternal beauty' of the city ${ }^{29}$. The evidence of the

\footnotetext{
${ }^{27}$ J. KOWALCZYK, op.cit., p. 139.

${ }^{28}$ S. Herbst, op.cit., p. 13.

${ }^{29}$ Teresa ZaręBSKA, Teoria urbanistyki włoskiej XV i XVI wieku, Warszawa 1971, p. 135.
} 
founder's aesthetic consciousness is the choice of the Italian architect Bernardo Morando, the permanent supervision of the project, the scrutiny of both individual elements and the whole project, e.g. Zamojski's refusal for the town to be disfigured with empty spaces or sheds ${ }^{30}$. The work of art was characterized by coherence, uniformity and harmony. The aesthetic value of the composition and form of the town was noticed permanently over the centuries. Bonifatius Vanozzi used the adjective 'decorative' to refer to the fortress ${ }^{31}$. According to Ulrich Werdum, the fortress looked "absolutely beautiful"32. Hacia Ali Aga (a Turkish envoy) underlined that: "it is nice to look at the combination of defence and sumptuousness" 33 . Ignacy Krasicki described the town as decorative, while Maria Dąbrowska compared it to a "brooch with pearls and coral against the golden-green-sapphire striped uniform" 34 .

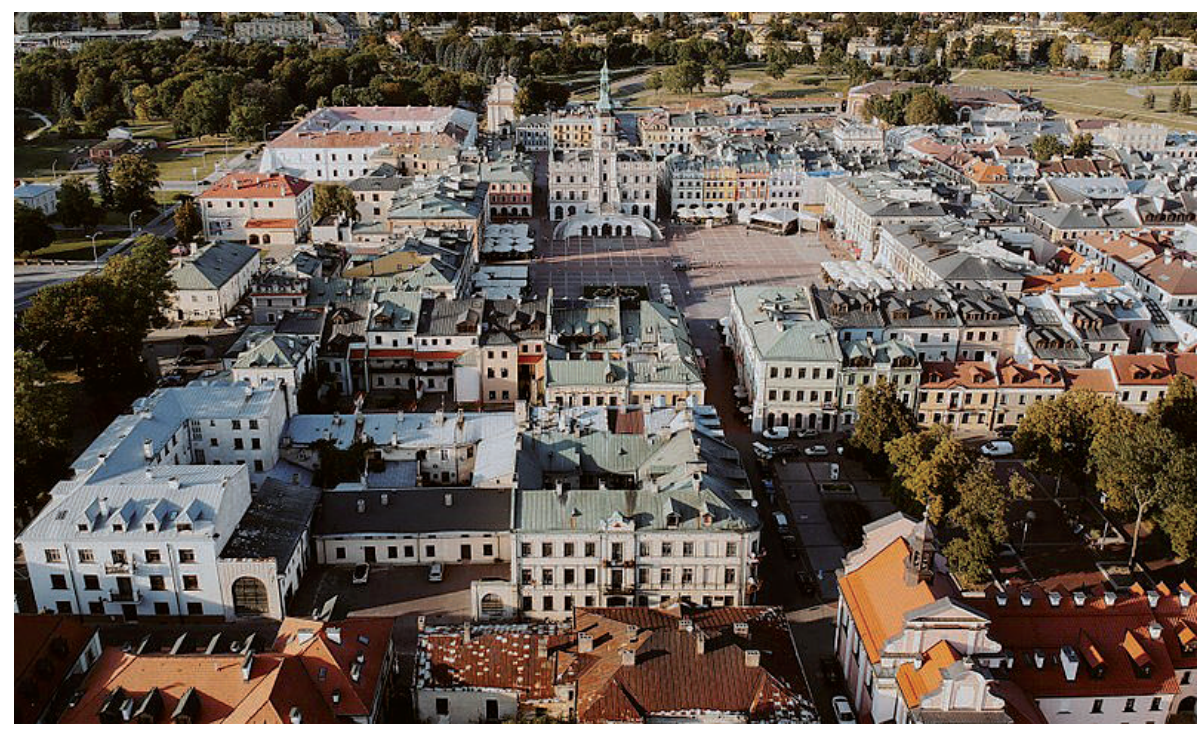

Il. 3. Old City of Zamość. Photograph taken from a height of $100 \mathrm{~m}$, Robert Danieluk, 31.08.2017

The metaphysical essence of Zamość was hidden in creative ideas and visualizations of the founder and the subsequent owners of the town, specific

${ }^{30}$ S. Herbst, op.cit., p. 20.

${ }^{31}$ J. U. NiemCEwicz, Zbiór pamiętników historycznych, p. 187.

${ }^{32}$ Ulryk Werdum 1670-1672, [in:] Cudzoziemcy w Polsce: L. Naker, U. Werdum, J. Bernoulli, J. E. Biester, J. J. Kausch, ed. Franciszek Ksawery Liszke, Lwów 1876, p. 114.

${ }^{33}$ After: Andrzej KęDZiora, op.cit., p. 265.

${ }^{34}$ M. DĄвrowska, op.cit., p. 873; Ignacy Krasicki, Dzieła Krasickiego. Dziesięć tomów $w$ jednym, Paryż-Genewa 1830, p. 146. 
forms of experiencing the city space, the mystery hidden in buildings which continue to function in the social consciousness despite the fact that they no longer exist.

The complex of architectural and urban elements of Zamość and their significance creates a certain code which enables to interpret the city in an appropriate way. The above mentioned elements such as gates, walls, sacral and secular buildings contribute to the legibility of the town's silhouette creating its symbolic dimension as asylum and the emblem of power ${ }^{35}$. When looked at in the distance, they reveal the ideology hidden in the project of the town evoking in the observer an unequivocal picture referring to their experience, emotions, reflections. The observer interprets the town as if it was the text written on paper. The observer filters the parts of the town with their memory, beliefs and expectations. Although interpretations of various observers may differ, some elements remain constant, which allows founders and architects to design a city in accordance with the established concept. Apart from the defensive role, Zamość was to be the centre of trade, craft and administration. Using modern terminology, the project of Zamość was a strategic image-building venture. However, the image is not created only on the basis of the whole picture but also on the basis of selected elements and impressions such as the location, the silhouette, the plan, architecture. We may refer here to the term Abbild - the real picture (picture-reflection) and Urbild - picture-archetype of Hans Belting ${ }^{36}$. In this perspective we should ponder on the relation between art and reality, and art as the interpretation of reality. To what an extent a created image reflected reality, and to what an extent it constructed it? According to Grzybowski, "Zamość was a precise realization of utopia"37. On the other hand, it fulfilled its role as a town-fortress. It was also a representative civitas - a monument which, according to Georg Dous (1598) allowed Zamojski to "leave behind a relic which is more lasting than pyramids and monuments not only in Poland, but also in whole Europe"38.

Taking into account the fact that the phenomenon of projection is in fact a process which takes place on the axis between the object and the observer, who creates reality, Zamość may be interpreted as a constructed deliberate creation - sculpture in the space and a miniature created in reality. In this sense, it would be an architectural and urban phenomenon - planned and carried out upon the initiative of one man who adapted the idea of a Renaissance town to local conditions. The choice of the date when the foundation privilege was

\footnotetext{
${ }^{35}$ Kevin Lynch, Obraz miasta, trans. Tomasz Jeleński, Kraków 2011, pp. 3-6.

${ }^{36}$ H. Belting, op.cit., p. 21.

${ }^{37}$ S. Grzybowski, op.cit., p. 176.

${ }^{38}$ J. KRZYŻANOWSKI, op.cit., p. 28.
} 
granted was not accidental, either. It was issued on 10 April 1580 - on the day of St. Thomas, the patron of the Zamojski clan.

Trans. by Agnieszka Chabros

Received 3 September 2018

Received in revised form 17 December 2018

Accepted 19 December 2018

Dr Natalia Bursiewicz

Institute of History and Archival Sciences

Pedagogical University of Cracow

e-mail: natalia.bursiewicz@up.krakow.pl

ORCID ID: 0000-0002-2037-0100

\section{Three-dimensional Aspect of the Town And Fortress \\ ON THE EXAMPLE OF ZaMość}

\section{Summary}

Key words: spatial analysis of Zamość, town planning, fortress town, Zamość Fortress, Zamość (Province of Lublin), spatial planning

The aim of the article is to look at Zamość as a three-dimensional spatial construct, which may be compared to an architectural and sculptural work of art. Analysing the external image of the town, its form, characteristic features, and dominant height one may broaden the interpretation by adding figurative, emotive or metaphysical aspects. The text constitutes the development of the thought of Stanisław Herbst, according to which Zamość was designed as a three-dimensional shape, not as a plan. The subject matter was examined using the sources of historical cartography and iconography along with modern aerial photographs. The text also includes the review of scientific publications concerning the subject matter. The observation of the town also played a major role.

\section{Der dreidimensionale Aspekt einer Festungsstadt AM BEISPIEL VON ZaMośĆ}

\section{Zusammenfassung}

Schlüsselwörter Raumanalyse von Zamość, Urbanistik, Festungsstadt, Festung Zamość, Zamość (Wojewodschaft Lublin), Raumplanung

Der Artikel möchte Zamość als dreidimensionales Raumkonstrukt betrachten, das man mit einem architektonisch-bildhauerischen Werk vergleichen kann. Durch die Analyse der äußeren Erscheinung der Stadt, ihrer Formen, Eigenschaften, Hö- 
hendominanten kann man die Interpretation um bestimmte Werte wie etwa den darstellerischen, den emotiven oder den metaphysischen erweitern. Zugleich ist der Text die Entfaltung eines Gedankens von Stanisław Herbst, wonach Zamość nicht als Plan, sondern als Block entworfen wurde. Das Thema wurde unter Benutzung von Quellen aus der historischen Kartografie und Ikonografie sowie von modernen Luftbildern ausgearbeitet. Dazu kommt ein Überblick über die wissenschaftlichen Veröffentlichungen zum gewählten Thema. Von Bedeutung war auch die unmittelbare Betrachtung der Stadt.

\section{TróJWYMIAROWY ASPEKT MIASTA TWIERDZY NA PRZYKŁADZIE ZAMOŚCIA}

\section{Streszczenie}

Słowa kluczowe: analiza przestrzenna Zamościa, urbanistyka, miasto twierdza, twierdza Zamość, Zamość (woj. lubelskie), planowanie przestrzenne

Artykuł ma na celu spojrzenie na Zamość jako na trójwymiarowy konstrukt przestrzenny, który można porównać z dziełem architektoniczno-rzeźbiarskim. Analizując zewnętrzy wizerunek miasta, jego formę cechy, dominanty wysokościowe, można poszerzyć interpretację o określone wartości, jak chociażby przedstawieniową, emotywną czy metafizyczną. Jednocześnie tekst jest rozwinięciem myśli Stanisława Herbsta, zgodnie z którą Zamość nie był projektowany jako plan, lecz jako bryła. Temat został opracowany przy wykorzystaniu źródeł historycznej kartografii i ikonografii oraz współczesnych zdjęć lotniczych. Dokonano ponadto przeglądu publikacji naukowych dotyczących wybranego zagadnienia. Niemałe znaczenie odegrała także bezpośrednia obserwacja miasta.

\section{BIBLIOGRAPHY}

Belting, Hans. Antropologia obrazu. Szkice do nauki o obrazie. Translated by Mariusz Bryl. Kraków: Universitas, 2007.

Bovet, August Andre. Zamoski, ville de Pologne au palatinate de Belz. Généve: Imprim. Litogr. de G. Charton, 1815-1853.

Czołowski, Aleksander. Plan i widok Zamościa z roku 1704. Zamość: nakł. Komitetu Obchodu 300-ej Rocznicy Zgonu Szymona Szymonowicza, 1929.

Dąbrowska, Maria. “Tydzień w Lubelskiem.” Bluszcz. Pismo tygodniowe ilustrowane dla kobiet, July 11, 1925.

Eysymontt, Rafał. Kod genetyczny miasta. Średniowieczne miasta lokacyjne Dolnego Śląska na tle urbanistyki europejskiej. Wrocław: Via Nova, 2009.

Giedion, Siegfried. Przestrzeń, czas i architektura. Narodziny nowej tradycji. Translated by Jerzy Olkiewicz. Warszawa: Państwowe Wydawnictwo Naukowe, 1968.

Gombrich, Ernst Hans. Sztuka i złudzenie. O psychologii przedstawiania obrazowego. Translated by Jan Zarański. Warszawa: Państwowy Instytut Wydawniczy, 1981. 
Grzybowski, Stanisław. Trzynaście miast. Czyli antynomie kultury europejskiej. Wrocław: Zakład Narodowy im. Ossolińskich, 2000.

Grzyś, Patrycja. "Wizerunek miasta a jego tożsamość - współczesne zależności." Architectus 2 (50) (2017): 3-13.

Herbst, Stanisław and Jan Zachwatowicz. Twierdza Zamość. Warszawa: Wydawnictwo Zakładu Architektury Polskiej i Historji Sztuki Politechniki Warszawskiej, 1936.

Herbst, Stanisław. Zamość. Warszawa: Budownictwo i Architektura, 1954.

Ingarden, Roman. Studia z estetyki, vol. 2. Warszawa: Państwowe Wydawnictwo Naukowe, 1958.

Jawor, Anna. Kultura w mieście idealnym. Kultura - Zamość - uczestnictwo w kulturze. Warszawa: Korporacja Polonia, 2009.

Kalinowski, Wojciech. “Zamość idealne miasto renesansu." In Czterysta lat Zamościa. Materiały sesji naukowej zorganizowanej przez Wydział I Nauk Społecznych Polskiej Akademii Nauk, Uniwersytet im. Marii Curie Skłodowskiej w Lublinie, Zamojskie Towarzystwo Przyjaciót Nauk, 12-13 czerwca 1980 r. w Zamościu, edited by Jerzy Kowalczyk, 87-93. Wrocław: Zakład Narodowy im. Ossolińskich, 1983.

Kędziora, Andrzej. Encyklopedia miasta Zamościa. Chełm: Towarzystwo Opieki nad Zabytkami, 2000.

Kotler, Philip, Christer Asplund, Irving Rein and Donald Haider. Marketing places Europe. How to attract investments, industries, residents and visitors to cities, communities, regions and nations in Europe. London: Financial Times Prentice Hall, 1999.

Kowalczyk, Jerzy. "Ideologiczne aspekty urbanistyki Zamościa." In Zamość i Zamojszczyzna w dziejach i kulturze polskiej, edited by Kazimierz Myśliński, 135-141. Zamość: Zamojskie Towarzystwo Przyjaciół Nauk, 1969.

Krasicki, Ignacy. Dzieła Krasickiego. Dziesięć tomów w jednym. Paryż, Genewa: Barbezat, 1830 .

Krzyżanowski, Julian. “Uczony holenderski na hetmańskim dworze.” Teka Zamojska 1/1 (1938): 24-29.

Liszke, Franciszek Ksawery, ed. Cudzoziemcy w Polsce: L. Naker, U. Werdum, J. Bernoulli, J. E. Biester, J. J. Kausch. Lwów: Gubrynowicz i Schmidt, 1876.

Lynch, Kevin. Obraz miasta. Translated by Tomasz Jeleński. Kraków: Wydawnictwo Archivolta, 2011.

Niemcewicz, Julian Ursyn. Juljana Ursyna Niemcewicza, podróże historyczne po ziemiach polskich od 1811 do 1828 roku. Petersburg: nakł. i dr. Bolesława Maurycego Wolffa, 1859.

Niemcewicz, Julian Ursyn. Zbiór pamiętników historycznych o dawnéy Polszcze z rękopismów, tudzież dzieł w różnych językach o Polszcze wydanych oraz z listami oryginalnemi królów i znakomitych ludzi w kraju naszym, vol. 2. Warszawa: [s.n.], 1822.

Przegon, Wojciech. Krajobrazy XIX-wiecznego Zamościa $w$ akwarelach i rysunkach Jana Pawła Lelewela. Kraków: Akapit, 1997.

Sienkiewicz, Henryk. Potop, vol. 3. Warszawa: Państwowy Instytut Wydawniczy, 1957.

Szczygieł, Ryszard, ed. Przywilej lokacyjny Zamościa z 1580 roku. Lublin: Wydawnictwo Lubelskie, 1980.

Zarębska, Teresa. Teoria urbanistyki włoskiej XV i XVI wieku. Warszawa: Państwowe Wydawnictwo Naukowe, 1971. 